\title{
Fall Prevention: Who's at Risk? ${ }^{1}$
}

\section{Sergio Romero ${ }^{2}$}

There are many risk factors associated with falls. Some risks are environmental, like poor lighting. Others relate to diseases people have or medications they take. It's important to know if you are at high risk of falling. Take this quiz to see if you are at risk! For each question, circle "yes" or "no."

\begin{tabular}{|l|c|}
\hline Do you take more than two medications daily? & Yes / No \\
\hline Have you or those around you noticed a change in your hearing? & Yes / No \\
\hline Do you wear glasses or have any vision problems? & Yes / No \\
\hline Have you fallen in the past year? & Yes / No \\
\hline $\begin{array}{l}\text { Do you have one or more of the following: Parkinson's disease, stroke, high } \\
\text { blood pressure, urinary incontinence, osteoporosis, multiple sclerosis, or } \\
\text { another neuromuscular disease? }\end{array}$ & Yes / No \\
\hline Do you get dizzy when you get up, change position, or walk? & Yes / No \\
\hline $\begin{array}{l}\text { Do you have trouble picking up objects from the floor, reaching overhead, } \\
\text { getting in and out of a chair, or walking without holding on to something? }\end{array}$ & Yes / No \\
\hline $\begin{array}{l}\text { Do you have throw rugs, stairs without rails, uneven surfaces, slippery } \\
\text { floors, or cluttered walkways in your house? }\end{array}$ & Yes / No \\
\hline Are you fearful of falling? & Yes / No \\
\hline Do you wear shoes with high heels or slippery soles? & Yes / No \\
\hline Do you have poor lighting conditions in your house? & Yes / No \\
\hline
\end{tabular}

If you answered "yes" to any of the questions, you may be at high risk for falling. Ask your doctor or health care provider about modifications and actions you can take to lower your risk of falling.

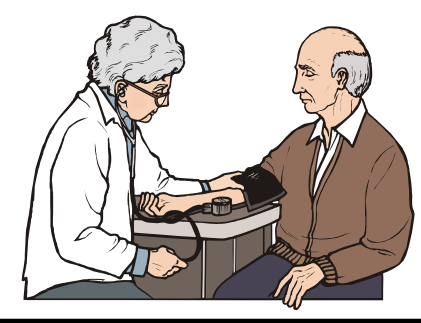

1. This document is FCS2227, one in a series of the Department of Family, Youth and Community Sciences, Florida Cooperative Extension Service, Institute of Food and Agricultural Sciences, University of Florida, Gainesville, FL 32611. Publication date: April 2005. Please visit the EDIS Website at http://edis.ifas.ufl.edu

2. Sergio Romero, MS, ATC, ENAFS education assistant, Department of Family, Youth and Community Sciences, Institute of Food and Agricultural Sciences, University of Florida, Gainesville, FL 32611. Reviewed by Leigh Ann Martin, MS and Linda B. Bobroff, PhD, RD, LD/N, Department of Family, Youth and Community Sciences, University of Florida.

The Institute of Food and Agricultural Sciences is an equal opportunity/affirmative action employer authorized to provide research, educational information and other services only to individuals and institutions that function without regard to race, color, sex, age, handicap, or national origin. For information on obtaining other extension publications, contact your county Cooperative Extension Service office. Florida Cooperative Extension Service / Institute of Food and Agricultural Sciences / University of Florida / Larry Arrington, Dean 